\title{
The Art of Necrophilia: Analogies between the Composition of Mishima Yukio's Novel The Sea of Fertility and the Composition of the Japanese Classical Nō Drama
}

\author{
Joanna Wolska \\ Jagiellonian University
}

The tetralogy The Sea of Fertility is the last work and opus magnum of Mishima Yukio (1925-1970). The Buddhist concept of the transmigration of souls is considered the axis of the novel, however analogies between the composition of the novel and the composition of the classical no drama are also significant for the structure of The Sea of Fertility.

Firstly, because the tetralogy, as well as the no drama, is founded on the antithetical assumption (as suggests Jadwiga Rodowicz in her book Aktor doskonaty) saying that "the extraordinary, uncommon, strange reality is hidden inside the ordinary reality and an uncommon Stranger is hidden inside a common person; what is more - these two [antithetical] realities co-exist".

The main characters of the tetralogy - thanks to the Buddhist concept of the transmigration - seem to transgress the reality and penetrate through the succeeding volumes of the novel. It can be said that the parts played by the main characters in the book are very much the same as those performed by the actors in the classical nō drama. For example: the plot of the nō drama is always focused on the protagonist called shite which means "the one who acts". Usually shite is an extraordinary person, in other words - "an uncommon Stranger". In the book this part falls successively to Kiyoaki's reincarnations: Isao and princess Jin Jan,

${ }^{1}$ J. Rodowicz, Aktor doskonały, (Gdańsk, 2000), p.21. 
whereas in the nō drama the part of "an uncommon Stranger" is mainly performed by a ghost, a suffering soul or a woman obsessed with love.

In the nō drama the protagonist is usually accompanied by a subordinate actor called waki which means "person on the side" or "witness"2. In the novel, this part is played by the closest friend of Kiyoaki - Honda Shigekuni, who is at the same time a passive but conscious observer, questing, following and writing down the events. In the nō drama waki always represents the human world - in the novel Honda is also an ordinary man ruled by the law of nature.

"Shite is responsible for the performance in its entirety" - says Estera Żeromska in her book Maska na japońskiej scenie. Od pradziejów do powstania teatru ${ }^{3}$ [the tetralogy is also founded on the existence of the four main characters]. She adds: "In the nō dramas shite, wandering through the time and space [in the tetralogy the time is cyclic], very often undergoes surprising transformations [in the book Kiyoaki transforms into his reincarnations: Isao and Jin Jan]: first shite appears as a real person and is called mae jite (shite from the first part of the drama) [his counterpart is Kiyoaki in the first volume of the book]; then shite appears as an unreal person and is called ato jite (or nochi jite) [Isao and Jin Jan in the succeeding volumes of the book]. In both cases it is the same actor [two reincarnations of the same protagonist - Kiyoaki; two, because Töru - the main character of the last volume of the tetralogy eventually tourned out to be $n i$ semono - the false incarnation]"4.

A part performed by shite is balanced with the part performed by waki-in other words - as notices E. Żeromska - "the one who acts" is confronted on the stage with "the one who stays torpid/motionless". Moreover, a waki actor is calling shite and waits for his arrival on the stage. He also initiates the conversation that usually stimulates shite's confession and plays the role of a confidant. In the first volume of the tetralogy Spring Snow (Haru no yuki) Honda frequently initiates conversation on Kiyoaki's love affair with Satoko, whereas in the second volume Runaway Horses (Homba) he plays a very similar role towards Isao who is planning the assassination of a prominent politician - Kurahara. In the third volume Honda's task is to peep through the keyhole of princess Jin Jan's erotic life and spy at nights at the young lovers in the park. Eventually, in the fourth volume of the novel The Decay of the Angel (Tennin gosui) Honda patiently waits for the ultimate confirmation of the last incarnation of Kiyoaki and for the ultimate proof of the existence of the transmigration of souls.

It should be added that the axis of the nō drama is "the transformation inside the protagonist provoked by the encounter of "the one who doesn't know" (waki)

\footnotetext{
${ }^{2}$ R. Tyler, Japanese Nō Dramas, (London, 2004), p. 8.

${ }^{3}$ E. Żeromska, Maska na japońskiej scenie. Od pradziejów do powstania teatru nō, Biblioteka Fundacji im. Takashimy, (Warszawa, 2003), p. 181.

${ }^{4}$ Ibid.

${ }^{5}$ Ibid.
} 
with "the one who knows" (shite) - as J. Rodowicz notices in Aktor doskonały. Therefore the content/the essence of the drama is not the conflict between characters, but the conflict inside the main character". It can be said the same about the tetralogy because the relationships between Kiyoaki and Honda, Isao and Honda, Jin Jan and Honda, and finally between Tōru and Honda in some way provoke the plot, and therefore the wonderful transformation, which Honda witnesses each time, seems to occur inside the main characters as a result of the process of transmigration in which Kiyoaki, Isao and Jin Jan are involved.

Another interesting notion is that the distinction between shite and waki can differ if we consider two categories of the nō, which are: genzainō and mugennō.

The first category genzaino depicts the world of living and real human beings (we can not deny anyway that the characters of the novel belong to the human world), while the other mugennō (sometimes referred to as "a drama of illusion"7) focuses on the ghost stories and the stories about the dead and demons returning from the afterworlds (in the tetralogy we have the yuishiki (consciousness-only) and the sansara concepts as well as oneiric motives which refer to the world of transcendence rather than to the real world).

As a consequence, the tetralogy and its structure can be considered, an example of the mugennō, however the distinction between shite and waki-according to Takahashi Tōru ${ }^{8}$ - will be different. Here - the part of wakibelongs to the Abbess of Gesshū Temple (Gesshūji) not to Honda, because the Abbess is the person who opens and closes the performance. In the tetralogy the Abbess (in the first volume of the book it is the great-aunt of Satoko) "opens" the novel introducing the concept of consciousness-only to the characters of the book and the reader by telling the story about a wanderer and a human skull'.

The Abbess also "closes" the book, confessing to Honda, who this time performs the role of shite, the ultimate truth about the yuishiki. In the last scene of the book Satoko - this time as the Abbess of Gesshū - casts doubts on the existence of Kiyoaki, Kiyoaki's incarnations and finally on Honda's himself - which of course refers to the essence of yuishiki (subjective awareness).

Moreover, Takahashi suggests that in mugennō the part of waki is to make shite feel nostalgic and provoke him to express feelings of sorrow and regret towards himself (in the tetralogy the memory of the sermons preached by the Abbess made Honda follow the trace of yuishiki). The appearance of waki in mugenno is limited to the minimum and is called mugen no omomi which means

\footnotetext{
'J. Rodowicz, Aktor doskonały, pp. 24-25.

'E. Żeromska, Maska, p. 178.

${ }^{8}$ T. Takahashi, Hōjō no umi no kōzō. Wakisō ni yoru ekō, in Mishima Yukio ronshū. Mishima Yukio no gendai, ed. T. Matsumoto, H. Satō Hideaki, T. Inoue, (Tokyo, 2001).

${ }^{9}$ The story refers to the fundamental doctrine of the Hossō sect, telling that all existence is based on subjective awareness. See: Y. Mishima, Haru no yuki. Hōjō no umi. Daikkan, Shinchō bunko, Shinchōsha, (Tokyo, 1969), pp. 36-37.
} 
"the important meaning without words" - in the book the Abbess plays the part of waki.

According to Takahashi, there is also fukushiki mugennō ("two-part mugenn $\overrightarrow{0}$ "), which consists of maeba, nakairi ("a natural intermission") when shite temporarily disappears from the stage and atoba or nochiba. Consequently, Takahashi suggests the following distinction in the tetralogy: the first two volumes (Haru no yuki and Homba) constitutes maeba which takes up the problem of transmigration; the first part of the third volume Akatsuki no tera (The Temple of Dawn) presents meticulous and time-consuming explanations of the concepts of transmigration (tensh $\vec{o}$ ) and sansara (rinne tensh $\overrightarrow{0}$ ) - this part Takahashi calles nakairi. Finally, the second part of the Akatsuki no tera and the last volume Tennin gosui constitute atoba which is dedicated to the concept of sansara.

It can be said that nakairi is the part similar to aikyogen (an interlude during a nō play) - during the nakairi a shite actor leaves the stage for a moment to change his costume or his make-up, in the meantime the wakitells the story of the drama with prose. Okano Moriya in his essay Nō to yuishiki calls this part of a play "a ballast" or "a balance beam"10 which makes an indispensable border between the two parts of the drama. Nevertheless, this part is often omitted or minimised by the audience - the same happens with the second part of the third volume of the tetralogy which is considered by many critics and readers the most complicated and the worst part of the book which enormously "slows down" the whole story.

In the mugenno usually the part of shite is performed by a ghost entangled with the world of human passions and desires who, for some reasons, is not able to experience the enlightenment (nirvana). Naturally, Honda isn't a ghost but considering the torture he suffers in the world of Buddhist delusion (meikal) - as Takahashi suggests - he can be regarded as such a creature.

In maeba, however, Honda plays the part of shite (mae jite) being a real person. In nakairi the identity of shite is only suggested, while in aikyogen shite (ato jite) changes his costume and then appears in atoba disguised as a ghost.

Honda doesn't look like as a ghost in the first two volumes of the book, however, in the last two volumes of the tetralogy his tragic fate as an old man who deals with the spying and is beaten by his adopted son seem to bring Honda down to the world of suffering (Asura's world - in other words - the world of the demons) which makes him resemble the shite (ato jite) in mugenno.

What is more, considering the structure of the book we could divide the tetralogy into maeba - the contemporary part including the first two volumes (the part of shite would fall on Kiyoaki's reincarnations, whereas Honda would be waki), and then nakairi and aikyōgen (the first part of Akatsuki no tera), telling about the concept of the transmigration of souls; atoba, the part dedicated to the

${ }^{10}$ M. Okano, Nō to yuishiki, p. 312. 
concept of the transmigration of souls, would "close" the tetralogy (the second part of Akatsuki no tera and Tennin gosui) - in this part Honda, wandering through the world of delusion (meikai), would be shite and the Abbess would play the part of waki.

There is no evidence that analogies between the structure of the tetralogy and the structure of the nō drama were intentional, however, author's liking for the classical nō theatre makes us think it was quite likely ${ }^{11}$.

One of the reasons why Mishima was so fascinated with nō, could be the fact that the nō is situated on the borderline of two arts - the art of war/dying and the art of word/poetry. Nō as "a distillate of these two arts merged together by music"12 was very like the same as bumbu ryōdo - the highest ethical principle for the Japanese samurai in the seventeenth and eighteenth centuries, which was also a kind of amalgam of the literary and the military arts. Naturally, Mishima was fully aware of this and he frequently pointed out the leading motive of death in the nō plays and its distinctive features such as specific beauty and elegance. Here I would like to quote Mishima:

お能と言うのはネクロフィラスな芸術だと思う。死体愛好症ですよね。言語表現がもう 突き抜けちゃったところに死体がいっぱいころがっている。幽霊がいます。お墓があり ます。その中で腐って骨があります。そういうものに優雅が直面しちやった。だからあ との時代にできた。そうしてその言菄自体は非常に優雅な言苯で、王朝時代の栄華を夢 みたり憧れたり思い出したりしているのですけれども、内容は死ですよ、死以外に何も ないい.

\footnotetext{
${ }^{11}$ Mishima's interest in nō is a well-known fact. Mishima recalls in the autobiographical book $M y$ Wandering Years (Watakushi no henreki jidai, 1964) that his grandmother, who was learning nō chanting at Kanze School, used to take him to see the performances when he was in the first class of secondary school. During his first visit to Yasuda Yojurō, that took place at the same time, young Kimitake asked Yasuda about his impression on the art of nō. Mishima recalls that the answer of the one of the most prominent romantics of those days didn't satisfy him. In spite of the young age, however, Mishima was fascinated with flowery style and characteristic aesthetics of the nō. What impressed him so much was probably - as suggests Ueda Makoto - "the unique combination of poetry and drama unlimited neither by space nor by time".

Yoshida Seiichi said that "the desire to revive mutual relationship between beauty and time was one of the reasons Mishima had chosen the nō". It ought to be mentioned that the essence of the Modern Nō Plays (Kindai nōgakushū,1956) was showing death on the stage, at least telling about it. And Mishima made it real. Jadwiga Rodowicz suggests that "nō is the quintessence of contradiction distinctive for the culture of Japan". The idea of contradiction is very much true in Mishima's case. In my opinion this contradiction could be one of the reasons of Mishima's fascination with nō. Moreover, the inner contradiction between being a writer and being a man of action lead Mishima to his very specific death. The aesthetic impression, which I call "the beauty of dying", can be considered the effect of this contradiction that can be observed both in the nō and in the writer's fate.

${ }^{12}$ J. Rodowicz, Aktor doskonaty, p. 23.

${ }^{13}$ Y. Mishima, in T. Aeba, Mishima Yukio to Nihon Rōmanha, "Kokubungaku. Kaishaku to kanshō" (Mishima Yukio to dekadansu) 2/1976, p. 58.
} 
The motive of death is also omnipresent in the tetralogy - each of the main characters, except of Töru - the false incarnation of Kiyoaki - dies at the age of 20 in order to join the cycle of death and rebirth. Consequently, in the first volume the main character dies because he profaned "sacredness" (secret love affair with Satoko who was betrothed to the Imperial Prince); the second volume focuses on the theme of battle and death that is symbolised in the novel by the scene of Isao's seppuku, the third volume depicts in detail death and the decay of the human body (ritual burning of bodies, the encounter with the lepers in India) and finally the fourth volume is the description of senility and death being the natural part of the human destiny.

According to Mishima, only death of the young is beautiful. As a consequence, Honda and Tōru's destiny is shown by symbolic "five signs of decay", prophesying ugliness, senility and dull death, lacking any romanticism.

Another interesting aspect is symbolism in the novel and in the nō drama. The symbolism of the space stage, costumes, colour of wigs, gestures are extremely important in the nō drama. In the novel all four main characters have signs which allow Honda to follow the incarnations of Kiyoaki. These are: three black moles on the left side of the chest and the symbolic moment of death of three, subsequent incarnations (three, because Töru - in spite of possessing three symbolic moles, turned out to be the title fallen "angel" excluded from the cycle of rebirth) - all of them die, at the age of 20 - Kiyoaki dies of pneumonia, Isao commits suicide and Jin Jan dies of a cobra bite.

The appearance of the dog's corpse during the stroll through the spring garden in the first volume gains also symbolic significance. Under the cloudless sky, in the clear water of the falls death unexpectedly appears. Then, in the same chapter the great-aunt of Satoko/the Abbess of Gesshüji mentions for the first time the concept of transmigration of the souls - the innocent remark of Kiyoaki's mother on dog's rebirth as a human being gently introduces the concept of umarekawari ("rebirth") to the reader.

There is one more scene in the novel worth mentioning regarding the problem of symbolism in the tetralogy and in the no drama. In the first chapter of the novel there is a description of the photo "Vicinity of Tokuri Temple: Memorial Service for the War Dead". In this description ambiguity and esoteric beauty, the very distinctive features of yuggen - the term identified by Zeami as "the highest aesthetic ideal which can be achieved in the art of nō"14 - dominate over the scene.

"The beauty of yuggen is quiet, delicate, subtle and ambiguous because it is founded on the knowledge that comes to us in a moment we realize the

\footnotetext{
${ }^{14}$ T. Izutsu, Metafizyczne tho teorii nō. Analiza "Dziewięciu etapów" Zeamiego, in Estetyka japońska. Antologia. Tom I. Wymiary przestrzeni, ed. K. Wilkoszewska, (Kraków, 2001), p. 71.
} 
non-substantial and limited nature of the human existence"15 - explains Izutsu Toshihiko. "It is beauty born from the mental aspiration and longing motivated by the desire of possessing sensual images of unutterable, unnatural reality covered by everlasting silence and remaining the secret in the heart of the world of phenomena" - says Izutsu about the essence of yügen.

The photograph, printed in sepia ink, emits subtle, melancholic beauty, which is a prophecy of approaching death and a symbol of the mystery of the transmigration.

セピア色のインキで印刷されたその写真は、ほかの雑多な戦争写真とはまるでちがって いる。構図がふしぎなほど絵画的で、数千人の兵士が、どう見ても画中の人物のように うまく配置されて、中央の高い一本の白木の墓標へ、すべての効果を集中させているの である゙。

This photograph, printed in sepia ink, was quite unlike the usual cluttered mementos of the war. It had been composed with an artist's eye for structure: it really made it seem as if the thousands of soldiers who were present were arranged deliberately, like figures in a painting, to focus the entire attention of the viewer on the tall cenotaph of unpainted wood in their midst ${ }^{17}$.

The tall cenotaph and the clumps of trees in the wind evoke the atmosphere of anxiety deepened by a strange half-light charged the entire plain with a sense of sorrow.

前景には都合六本の、大そう丈の高い救々が、それぞれのバランスを保ち、程のよい間 隔をもってそびえ立っている。木の種類はわからないが、亭々として、梢の葉叢を悲壮 に風になびかせている。

そして野のひろがりはかなたに微光を放ち、手前には荒れた草ヶがひれ伏している。画 面の丁度中央に、小さく、白木の墓標之白布をひるがえした祭壇、その上に置かれた花々 が見える ${ }^{18}$ 。

Six very tall trees stood at graceful intervals in the foreground, each placed so as to complement the overall harmony of the landscape. It was impossible to tell what kind they were, but their heavy top branches seemed to bend in the wind with a tragic grandeur. The distant expanse of plains glowed faintly; this side of the mountains, the vegetation lay flat and desolate. At the center of the picture, minute, stood the plain wooden cenotaph and the altar with flowers lying on it, its white cloth twisted by the wind ${ }^{19}$.

\footnotetext{
${ }^{15}$ Ibid., p. 73.

${ }^{16}$ Y. Mishima, Haru no yuki. Hōjō no..., pp. 5-6.

${ }^{17}$ Idem, Spring Snow. The Sea of Fertility. A Cycle of Four Novels, trans. M. Gallagher, pp. 3-4.

${ }^{18}$ Idem, Haru no yuki. Hōjō no..., p. 6.

${ }^{19}$ Idem, Spring Snow. The Sea of..., p. 4.
} 
However, the most tragic aspect is the fate of soldiers who are soon going to die like their comrades who have already fallen in the battle.

その他はみんな兵隊、何千と言う兵隊だ。前景の兵隊はことごとく、軍帽から垂れた白 い覆布と肩から掛けた斜めの革ひもを見せて背を向け、きちんとした列を作らずに、乱 れて、群がって、うなだれている。わずかに左隅の前景の数人の兵士が、ルネサンス画 中の人のように、こちらへ半ば暗い顔を向けている。[...]

前景の兵士たちも、後景の兵士たちも、ふしぎな沈んだ微光に犯され、脚料や長靴の輪 郭をしらじらと光らせ、うつむいた項や有の線を光らせている。画面いっばいに、何と も言えない沈痛の気が涱っているのはそのためである20。

For the rest you saw nothing but soldiers, thousands of them. In the foreground, they were turned away from the camera to reveal the white sunshields hanging from their caps and the diagonal leather straps across their backs. They had not formed up in neat ranks, but were clustered in groups, heads drooping. A mere handful in the lower left corner had half-turned their dark faces toward the camera, like figures in a Renaissance painting.[...] The figures of these soldiers, in both foreground and rear, were bathed in a strange half-light that outlined leggings and boots and picked out the curves of bent shoulders and the napes of necks. This light charged the entire picture with an indescribable sense of grief $^{21}$.

"An indescribable sense of grief" and "a strange half-light" in which the soldiers are bathed seem to be an allusion to the mysterious light of the moon. This light will accompany the main characters as a symbol of karmic transformations to the very end of the novel.

すべては中央の、小さな白い祭壇と、花と、募標人向かって、波のように押し奇せる心 を捧げているのだ。野の果てまでひろがるその大きな集団から、一つの、ロにつくせ女 思いが、中央一向かって、その思い鉄の上うな巨大な環を徐々にしめつけてい22。

From these men, there emanated a tangible emotion that broke in a wave against small whit altar, the flowers, the cenotaph in their midst. From this enormous mass stretching to the eds of the plain, a single thought, beyond all power of human expression, bore down like a gre: heavy ring of iron on the center ${ }^{23}$.

"The edge of the plain" points out the existence of "another world". The s diers doomed to death and the white simple cenotaph evoke an atmosphere infinite poignancy. This symbolic scene, like a phantom of the nō drama, $v$

\footnotetext{
${ }^{20}$ Idem, Haru no yuki Hōjō no..., p. 6.

${ }^{21}$ Idem, Spring Snow, The Sea of..., p. 4.

${ }^{22}$ Idem, Haru no yuki. Höjö no..., p. 7.

${ }^{23}$ Idem, Spring Snow. The Sea of..., pp. 4-5.
} 
appear once more during the romantic ride of young lovers through the snowy streets of Tokio in the twelfth chapter of the first volume of the book. Just as the dog's corpse discovered on a warm sunny day during the stroll through the autumn garden, illusory soldiers in the picture of the memorial ceremony near Tokuri Temple for the fallen of the Russo-Japanese War destroy the idyllic atmosphere of the first kisses exchanged between beautiful Satoko and Kiyoaki. This scene will become further a symbol of Kiyoaki's destiny and an omen of already mentioned "unnatural reality covered by everlasting silence".

Another symbol worth mentioning here is a "tie" linking all karmic incarnations, namely the Kitazaki Inn where the young lovers secretly met. It is also a place where Isao and his companions used to meet with Lieutenant Hori in order to plan coup d'etat under the name of The Shōwa League of the Divine Wind. When young Isao sees this place for the first time, he feels he has already been there. The same sensation accompanies him when he meets Prince Tōin - Satoko's fiance. Moreover, the owner of the Kitazaki Inn - eighty year old Mr Kitazaki - insists during Isao's trial that 20 years earlier young linuma Isao brought a woman with him to the Inn...

Also worth mentioning is an emerald ring that symbolises the cycle of transmigration in the novel. The ring belonged to the Siamese Prince Chao P.'s fiancee, Princess Chantrapa ("Moonlight") who unexpectedly died at a very young age. Chao P. and his cousin Prince Kridsada were guests of Marquis Matsugae and both attended The School of Peers (Gakushūin) together with Kiyoaki and Honda. Chao P. lost the ring in unexplained circumstances while staying in Japan. After more then 20 years, during the Second World War, Honda had found the ring accidentally at a pawn shop in Tokyo whose owner was... Satoko's fiance, Prince Tōin.

Finally, one of Kiyoaki's dreams takes place in Siam. In this dream Kiyoaki sees the chamber full of peacocks flying under the ceiling - the scene announces the next incarnation of Kiyoaki - this time in the body of a beautiful woman (Princess Jin Jan). In addition, the scene refers to "The Sutra of the Peacock Wisdom King" ("Daikinjiki kujaku myōōkyō"), which is significant because in India "a peacock" is a symbol of love which is also the subject of the third volume of the tetralogy.

Lastly, I would like to refer to the famous no plays in the text of the tetralogy.

In the nineteenth chapter of the second volume of the tetralogy Honda goes to the theatre to see the play Pining Wind (Matsukaze). In this play "regarded as one of the most beautiful plays in the repertoire"24 appears the theme of the moon that reflects in the brine cart drawn by the ghosts of two sisters Matsukaze (Pining Wind) and Murasame (Autumn Rain). The illusory reflection of the moon also refers to the ambiguous title of the tetralogy (The Sea of Fertility, in Latin "Mare Fecunditatis", indicates the barren crater on the surface of the moon).

${ }^{24}$ R. Tyler, Japanese Nō Dramas, p. 183 
Furthermore, "five signs" predicting "the decay" of a heavenly maiden from the play The Feather Mantle (Hagoromo) became one of the leading motives of the last volume of the tetralogy The Decay of the Angel (Tennin gosui). It is the reading of the play (Hagoromo) that made Honda travel to the famous pine grove of Miho - the place, where a celestial maiden descends from the sky and hangs over her mantle on a pine. In the neighborhood of the grove, Honda comes across a signal station where he first meets Tōru - the sixteen year old boy with three symbolic moles on the left side of his chest. He decided to adopt the boy regarding him the next incarnation of Kiyoaki. At the end of the novel, however, Tōru, disappointed with the lack of destiny of "the choosen one", attempts to commit suicide, but in vain. As a result, he goes blind. What is more, five Buddhist signs (Hagoromo mentions only withered flowers in the hair) predict the decay of the title Angel.

Matsukaze and Hagoromo have a significant meaning for the process of forming the plot of the novel as the points of reference enabling the analyses of the novel in the semantic connection with its title. Both plays suggest possible direction of the "re-writing" of the text and point out one of the multiple "entrances" to the text of the novel.

To sum up, the role types, the division of the plot, the antithetical concept of the transmigration of souls and finally the motive of beautiful death in the structure of the book correspond with the very similar aspects in the structure of the classical nō theatre.

\section{Bibliography}

Aeba, T. (1976). “Mishima Yukio to Nihon Rōmanha", in: Kokubungaku. Kaishaku to kanshō, Tokyo; Shibundō, pp. 58

Izutsu, T. (2001). Metafizyczne tło teorii nō. Analiza "Dziewięciu etapów" Zeamiego, in: Estetyka japońska. Antologia. Vol. I. Wymiary przestrzeni, ed. K. Wilkoszewska, Krakow: Universitas, pp. 71-73

Mishima, Y. (1969). Haru no yuki. Hōjō no umi. Daikkan, Tokyo: Shinchō bunko, Shinchōsha. Mishima, Y. (1990). Spring Snow. The Sea of Fertility. A Cycle of Four Novels, trans. M. Gallagher. New York: Vintage International, Vintage Books, A Division of Random House, Inc. Mishima, Y. (1995). Watashi no henreki jidai, Tokyo: Chikuma bunko.

Rodowicz, J. (2000). Aktor doskonały, Gdansk: Słowa/obraz terytoria.

Takahashi, T. (2001). Hōjō no umi no kōzō. Wakisō ni yoru ekō, in: Mishima Yukio ronshū. Mishima

Yukio no gendai, ed. T. Matsumoto, H. Satō, T. Inoue, Tokyo: Bensei Shuppan, pp. 312-314.

Tyler, R. (2004). Japanese Nō Dramas, London: Penguin Books.

Żeromska, E. (2004). Maska na japońskiej scenie. Od pradziejów do powstania teatru nō, Warszawa: Wydawnictwo TRIO, Biblioteka Fundacji im. Takashimy. 